\title{
PERBEDAAN HASIL BELAJAR MATEMATIKA SISWA DENGAN METODE BEHAVIOR MODIFICATION DAN METODE GUIDED DISCOVERY PADA POKOK BAHASAN KUBUS DAN BALOK DI KELAS VIII SMP NEGERI I MERBAU
}

\author{
Indah Fitria Rahma', Nurlina Ariani Hrp ${ }^{2}$,Rohani ${ }^{3}$ \\ ${ }^{12}$ Program Studi Pendidikan Matematika, STKIP Labuhan Batu, Jalan SM Raja No 126 A, Aek Tapa, Rantauprapat \\ Email:1indahfitria286@gmail.com, 2nurlinaariani@yahoo.com,3pasariburohani@gmail.com
}

Diterima (Maret 2018) dan disetujui (April 2018)

\begin{abstract}
ABSTRAK
Tujuan penelitian ini adalah untuk mengetahui apakah perbedaan hasil belajar matematika siswa yang di ajar dengan metode behavior modification dan guided discovery pada bahasan kubus dan balok dikelas VIII SMP Negeri 1 Marbau. Tempat penelitian ini dilaksanakan di SMP Negeri 1 Marbau Kabupaten Labuhanbatu. Dalam penelitian ini populasi adalah seluruh siswa kelas VIII SMP Negeri 1 Marbau tahun ajaran 2014/2015 yang berjumlah 230 dan dibagi menjadi 6 kelas yang dibagi tidak berdasarkan tingkat kemampuan siswa artinya siswa disebar secara merata. Metode yang digunakan adalah metode kuasi (semu) sebab kondisi-kondisi siswa tidak dapat dikontrol secara keseluruhan, seperti : pengerjaan rumah, hubungan siswa dengan orang tua, hubungan siswa dengan lingkungan tempat tinggal, dimana penelitian dilaksanakan pada 2 kelas yaitu kelas eksperimen 1 dan eksperimen 2. Dari hasil perhitungan pengujian hipotesis tes, kriteria pengujian adalah thitung $>\mathrm{t}_{\left(1-\frac{1}{2}\right.}$ a) dari perhitungan diatas diperoleh thitung $=2,37$ dan trabel $=1,997$ artinya bahwa $\mathrm{H}_{0}$ ditolak $\mathrm{H}_{\mathrm{a}}$ diterima. Dengan demikian maka dapat disimpulkan bahwa ada perbedaan yang signifikan antara hasil belajar siswa yang diajar dengan metode behavior modification dengan metode guided discovery pada pokok bahasan kubus dan balok dikelas VIII SMP Negeri 1 Marbau tahun ajaran 2014/2015. Kesulitan belajar matematika yang masih dialami siswa dalam pembelajaran metode behavior modification dalam mempelajari pokok bahasan kubus dan balok di kelas VIII SMP Negeri 1 Marbau yaitu siswa kesulitan dalam memahami soal dan siswa kesulitan menyatakan soal dalam bentuk matematika
\end{abstract}

Kata Kunci: Behavior modification, Guided discovery 


\section{PENDAHULUAN}

Pendidikan merupakan kebutuhan sepanjang hayat, setiap manusia membutuhkan pendidikan, sampai kapan dan dimanapun ia berada. Pendidikan sangat penting artinya, sebab tanpa pendidikan manusia akan sulit berkembang dan bahkan akan terbelakang. Dengan demikian pendidikan harus betul-betul diarahkan untuk menghasilkan manusia yang berkualitas dan mampu bersaing, disamping memiliki budi pekerti yang luhur dan moral yang baik.

Pemerintah Indonesia juga memahami arti pentingnya pendidikan bagi warga Negaranya. Sejak berdirinya Negara, pendidikan telah tercantum sebagai salah satu tujuan utama bangsa ini yakni yang tersirat dalam kata mencerdaskan kehidupan bangsa. Ini bukanlah hal yang spontanitas keluar ketika sebuah Negara baru merdeka, bahkan pemerintah membangun sebuah komitmen yang terdapat dalam program wajib belajar untuk seluruh warga Negara Indonesia dan berbagai sarana-sarana dalam pendidikan semakin ditingkatkan sehingga dapat meningkatkan mutu pendidikan.

Salah satu wadah kegiatan yang dipandang mampu menciptakan SDM yang berkualitas adalah pendidikan matematika. Matematika merupakan salah satu pelajaranyang diajar pada setiap jenjang pendidikan di Indonesia mulai dari sekolah dasar (SD) sampai sekolah menengah atas (SMA). Hal ini sesuai salah satu tujuan pendidikan matematika ( GBPP matematika SMU 1995:1) yaitu " mempersiapkan siswa agar sanggup menghadapi perubahan keadaan didalam kehidupan dan dunia yang selalu berkembang, melalui latihan, bertindak atas dasar pemikiran secara logis, rasional, kritis, cermat, jujur, efektif, dan efisien".

Pengalaman peneliti selama melakukan observasi yaitu banyak siswa yang kurang mengkuasai konsep matematika karena siswa terbiasa menghafal rumus, sehingga siswa tidak percaya diri dan sulit dalam menyelesaikan permasalahan yang menyangkut matematika. Ketidak percayaan diri siswa disebabkan karena siswa kurang latihan bahkan guru lebih banyak menyelesaikan soal dari pada siswa itu sendiri sehingga perubahan-perubahan tingkah laku pembelajaran siswa sama sekali kurang ( pasif ).

Untuk itu adapun usaha yang dilakukan untuk memperbaiki atau meningkatkan hasil belajar matematika tersebut adalah dengan meningkatkan kompetensi guru dalam memilih strategi pembelajaran yang dapat meningkatkan keterlibatan siswa dalam proses pembelajaran karena sampai sekarang ini masih banyak siswa yang mengeluh bahkan menjadikan matematika sebagai momok yang menakutkan sehingga mereka menjadi malas untuk mereka lebih mendalami lagi mempelajari matematika. Kebanyakan dari siswa mempunyai kesulitan dalam memahami konsep. Khususnya tentang konsep kubus dan balok. Dalam mempelajari kubus dan balok siswa mengalami kesulitan dalam penggunaan rumus dalam menyelesaikan soal-soal. Salah satu penyebab siswa mengalami kesulitan dalam memahami konsep karena siswa tidak dibiarkan untuk menyelesaikan atau membuktikan sesuatu konsep yang diberika hingga siswa cenderung kurang aktif yang menyebabkan perbuatan-perbuatan atau tingkah laku dari siswa kurang terampil dalam menyelesaikan soal.

Berkaitan dengan uraian tersebut maka perlu dipikirkan dan strategi untuk mengatasi permasalahan di atas. Salah satu metode mengajar yang diterapkan dalam belajar adalah metode guided discovery. Dengan menggunakan metode guided discovery ini menantang peserta didik untuk merasa dewasa terlibat atau berpartisipasi dalam aktifitas pembelajaran. Peranan guru hanyalah sebagai pasilitator dan bimbingan atau pemimpin pengajaran yang demokratis, sehingga diharapkan peserta didik lebih banyak melakukan kegiatan sendiri atau dalam bentuk kelompok memecahkan masalah atas bimbingan guru.

Metode yang lain dapat diterapkan dalam belajar matematika adalah metode behavior modification.

Mempelajari kubus dan balok bukan hanya kemampuan menentukan jawab akhir dan mutlak tetapi juga untuk memperoleh ketangkasan dan keterampilan harus diperlukan suatu keaktifan siswa dengan mengerjakan sendiri dan memecahkan masalah sendiri dari suatu konsep yang diberikan. Oleh sebab itu, penulis tertarik untuk mengadakan penelitian dengan judul perbedaan hasil belajar matematika yang diajarkan dengan 
Hal $44-47$

metode behavior modification dan guided discovery pada pokok pembahasan kubus dan balok.

\section{Metode}

Tempat penelitian ini dilaksanakan di SMP Negeri 1 Marbau Kabupaten Labuhanbatu. Dalam penelitian ini populasi adalah seluruh siswa kelas VIII SMP Negeri 1 Marbau tahun ajaran 2014/2015 yang berjumlah 230 dan dibagi menjadi 6 kelas yang dibagi tidak berdasarkan tingkat kemampuan siswa artinya siswa disebar secara merata. sampel dalam penelitian ini dipilih 2 kelas dari 6 kelas secara random sampling, artinya setiap kelas mempunyai peluang yang sama untuk dijadikan sampel. Sampel dalam penelitian yaitu satu kelas diambil kelas sebagai kelas eksperimen satu yaitu kelas VIII-3 dan eksperimen 2 kelas VIII-6. Jenis penelitian yang digunakan adalah penelitian eksperimen. Metode yang digunakan adalah metode kuasi (semu) sebab kondisi-kondisi siswa tidak dapat dikontrol secara keseluruhan, seperti : pengerjaan rumah, hubungan siswa dengan orang tua, hubungan siswa dengan lingkungan tempat tinggal, dimana penelitian dilaksanakan pada 2 kelas yaitu kelas eksperimen 1 dan eksperimen 2. Data dalam penelitian ini terbentuk kualitatif dan kuantitatifnya. Data bentuk kualitatif berguna untuk menentukan data yang terbentuk kata-kata seperti hasil observasi dan hasil wawancara. Data bentuk kuantitaf berguna untuk menentukan hasil belajar siswa yang terbentuk angka yaitu dari tes hasil belajar siswa.

\section{HASIL DAN PEMBAHASAN}

Berdasarkan analisis data diperoleh data hasil belajar siswa yang diajarkan dengan metode behavior modification dan metode guided discovery pada tabel berikut:

Tabel 1. Deskripsi Data Hasil Belajar

\begin{tabular}{|l|c|c|c|}
\hline \multirow{2}{*}{ No } & \multirow{2}{*}{ Keterangan } & Metode Behavior Modification & Metode Guided discovery \\
\cline { 3 - 4 } & $\mathrm{N}$ & Post tes & Post tes \\
\hline 1 & $\bar{X}$ & 36 & 34 \\
\hline 2 & $\sum X$ & 77,61 & 70,79 \\
\hline 3 & SD & 2794 & 2407 \\
\hline 4 & & 11,51 & 12,52 \\
\hline
\end{tabular}

Dari tabel diatas diperoleh beda tingkat hasil belajar siswa pada pokok bahasan kubus dan balok dengan menggunakan metode behavior modification dan menggunakan metode guided discovery adalah $(77,61-70,79)=6,82$ atau tidak sama nol, karena beda tingkat hasil belajar pada pokok bahasan kubus dan balok antara pengajaran dengan metode behavior modification dan pengajaran dengan metode guided discovery sebesar 7,01 maka dapat disimpulkan bahwa ada perbedaan antara hasil belajar siswa yang diajar dengan metode behavior modification dengan metode guided discovery.

Dari hasil perhitungan pengujian hipotesis tes, kriteria pengujian adalah thitung $>\mathrm{t}_{\left(1-\frac{1}{2}\right.}$ a) dari perhitungan diatas diperoleh thitung $=2,37$ dan tabel $=1,997$ artinya bahwa $\mathrm{H}_{0}$ ditolak $\mathrm{H}_{\mathrm{a}}$ diterima. Dengan demikian maka dapat disimpulkan bahwa ada perbedaan yang signifikan antara hasil belajar siswa yang diajar dengan metode behavior modification dengan metode guided discovery.

\section{KESIMPULAN}

Berdasarkan analisis terhadap data penelitian maka dapat disimpulkan bahwa ada perbedaan yang signifikan antara hasil belajar siswa yang diajar dengan metode behavior modification dengan hasil belajar siswa yang diajar dengan guided discovery pada pokok bahasan kubus dan balok dikelas VIII SMP Negeri 1 Marbau tahun ajaran 2014/2015. Kesulitan belajar matematika yang masih dialami siswa dalam pembelajaran metode behavior modification dalam mempelajari pokok bahasan kubus dan balok di kelas VIII SMP Negeri 1 Marbau yaitu Siswa kesulitan dalam memahami soal, Siswa kesulitan menyatakan soal dalam bentuk matematika. Kesulitan belajar matematika dalam pembelajaran metode guided discovery yang masih dialami siswa dalam mempelajari pokok bahasan kubus dan balok dikelas VIII SMP Negeri 1 Marbau yaitu Siswa kesulitan dalam memahami soal, Siswa kesulitan menyatakan soal 
Hal 44 - 47

dalam bentuk matematika, Siswa kesulitan mengingat rumus dan Siswa kurang teliti dalam perhitungan.

\section{DAFTAR PUSTAKA}

Ali, M., Ismail, Z., (2004); Assessing Student Teachers Understanding of The Biology Through Concept Mapping, Universiti Sains Malaysia.

Baharuddin et, al, Teori Belajar dan Pembelajaran, Jogjakarta : Ar-Ruzz Media, 2008, Cet.III

Branen, Julia, Memadu Penelitian Kualitatif dan Kuantitatif, Yogyakarta: Pustaka Pelajar, 2004, Cet. IV

Dahar, Ratna Willis. 2011. Teori Belajar dan Pembelajaran. Jakarta : Penerbit Erlangga.

Djamarah \& Zain. (2006). Strategi belajar mengajar. Jakarta: Rineka Cipta.

Djamarah \& Zain. (2013). Strategi belajar mengajar. Jakarta: Rineka Cipta.

Hamalik, Oemar. 2011. Kurikulum dan Pembelajaran. Jakarta: Bumi Aksara.

Hamzah, B. Uno. 2010. Model Pembelajaran Menciptakan Proses Belajar Mengajar yang Kreatif dan Efektif. Jakarta: Bumi Aksara.

Hidayat, Robby. 2005. Wawasan Seni Tari. Malang: Perpustakaan Nasional.

Hasibuan, J.J. dan Moedjiono, Proses Belajar Mengajar, Bandung: PT. Remaja Rosdakarya, 2000

Mulyoto. 2013. Strategi Pembelajaran Di Era Kurikulum 2013. Jakarta : Prestasi Pustaka Karaya.

Nasution, S. 1982. Berbagai Pendekatan Dalam Proses Belajar Mengajar. Bandung : Bumi Aksara.

Shoimin, Aris. 2014. 68 Model Pembelajaran Inovatif dalam Kurikulum 2013. Yogyakarta : Ar-ruzz Media.

Sanjaya, Wina. 2009. Strategi Pembelajaran Berorientasi Standar Proses Pendidikan. Jakarta : Kencana.
Sitanggang, Natanel. 2013. Variable Penentu Kepemimpinan Pendidikan Kejuruan. Medan : Unimed Press.

Situmorang, Benyamin. 2013. Penelitian dan Pendidikan Konsep dan Implikasi. Medan : Unimed Press

Sudjana. 2001. Metoda Statistika. Bandung : Tarsito. Sukardi. 2007. Metodologi

Penelitian Pendidikan. Yogyakarta : Bumi Aksara. 